\title{
A CASE STUDY ON THE USES OF BAND APP AT A SOUTH KOREAN UNIVERSITY
}

\author{
Hasan TINMAZ 1
}

Geliş: 01.12.2020 / Kabul: 25.01.2021

DOI: 10.29029/busbed.834250

\begin{abstract}
The recent advancements in mobile technologies and widespread use of social media have initiated the utilization of different mobile social media apps in educational context. In many cases, the focus of attention has been the adaptation of these apps on teaching/learning processes. Unfortunately, providing communication among educational institutions or supporting administration processes has been underestimated. This paper shows an implementation of a social media app called "Band" from South Korea. The researcher focused on a private institution in which the Band app was utilized for nearly two years to serve administration and communicative purposes among students, professors and managers. This paper demonstrates how to use the Band app, its usage statistics for two years, survey results from students $(n=52)$ and email interviews from professors $(n=5)$. Although both professors and students have some issues (such as the quality of some contents and frequency of posts), the general findings about the adaptation of the Band app were positive enough to support its contribution to the faculty.
\end{abstract}

Keywords: Instructional Technology, Educational Management, Higher Education, South Korea, Band.

\footnotetext{
1 Assistant Professor, Technology Studies - Woosong University, South Korea, hasan_tinmaz@hotmail.com, ORCID: https://orcid.org/0000-0003-4310-0848.
} 


\section{BİR GÜNEY KORE ÜNIVERSITESINDE BAND APP'IN KULLANIMI ÜZERINE BİR DURUM ÇALIŞMASI}

$\ddot{O} z$

Mobil teknolojilerdeki son gelişmeler ve sosyal medyanın yaygın kullanımı, farkl mobil sosyal medya uygulamalarının eğitim ortamlarında kullanılmasına yol açmıştır. Birçok durumda, bu uygulamaların odağ öğretme / öğrenme süreçlerine uyarlanması şeklinde olmuştur. Ne yazık ki, eğitim kurumu bünyesinde iletişimin sağlanması veya yönetim süreçlerinde destekleyici araç olarak kullanılması boyutları gözardı edilmistir. Bu makale Güney Kore'den "Band" adl sosyal medya uygulamasinin bir uygulamasinı sunmaktadir. Araştırmacı, Band uygulamasının öğrenciler, ögretim elemanlarl ve yöneticiler arasında yönetim ve iletişim amaçlarına hizmet etmek üzere kullanıldığı özel bir kuruma odaklanmaktadır. Bu çalışma, Band uygulamasının iki yıllık kullanım istatistiklerini, öğrenci anket sonuçlarını $(n=52)$ ve öğretim elemanları $(n=5)$ e-posta görüşmelerini içermektedir. Hem öğretim elemanlarının hem de öğrencilerin bazı endişeleri olmasına rağmen (bazı içeriklerin kalitesi ve gönderilerin sıklı̆̆ gibi), Band uygulamasının kuruma uyarlanmasılyla ilgili genel bulgular fakülteye olumlu katklsinı destekleyecek niteliktedir.

Anahtar Kelimeler: Öğretim Teknolojisi, Ĕgitim Yönetimi, Yüksek Ögretim, Güney Kore, Band.

\section{Introduction}

While economic crises have been carrying many budget shortcuts to higher education institutions, well-accepted and pervasive uses of ICTs are offering innovative sources of support for universities (Timmis, 2012). Panigrahi, Srivastava and Sharma (2018) stated that ICT use has the potential to diminish the number or the effect of problems stemming from the traditional instructional approaches. Furthermore, Au-Yong-Oliveira, Gonçalves, Martins and Branco (2018) acknowledged "information technology (IT) is a precious partner in class..." (p. 955). Therefore, different course instructors must attempt to find ways to take advantage of these social media tools (especially messaging tools) for educational purposes in different dimensions (instructional or administrative), other than fighting against that online tools.

In recent cases, many universities create and manage their profiles on different social media platforms for free in order to communicate with their students (such as university news or events), or student candidates (marketing for student admissions), or their graduates. Uses of different social media platforms 
blur the formal border between students and other educational stakeholders (Roblyer, McDaniel, Webb, Herman \& Witty, 2010). In early research, Jones, Edwards and Reid (2009) explain from their case study that the students are apt to accept administrative uses of social media tools more than their instructional implementations, especially when they move from traditional context to more technology dominated context. Unfortunately, pedagogical concerns and organizational constraints prevent many higher education institutions from fully using social media in their bodies (Manca \& Ranieri, 2016).

\section{Literature Review}

The maintenance of instructional processes and procedures to make best use of the mobile technologies in higher education is indispensably essential. Hence, considering only learning or content management systems as mobile applications in higher education makes the educational stakeholders partially blind to other applications such as the focus on administration or organization oriented mobile tools or applications (Al-Emran, Elsherif, \& Shaalan, 2016).

Although there are different research studies on the usages of different social media tools for instructional purposes, there is a research shortage on the usage of social media for administrative purposes in educational institutions. However, as So (2016) stated, social media tools could serve two major purposes in educational institutions; supplementary to teaching and learning processes or support the management issues in the forms of communication and administration. There are different research studies showing the positive administrative contribution of different social media tools in higher education institutions (Goh, Seet, \& Chen, 2012; Jones, Edwards, \& Reid, 2009; Naismith, 2007; So, 2016).

For example, Naismith (2007) reported a successful case study from an Australian university where social media was utilized to assist administrative communication informing students about received messages about classroom time/place changes, reminders about the academic calendar or upcoming school events. Naismith added that administration personnel who were in charge of writing the posts for the students had problems about the appropriateness of the content. Hence, for few cases, the students had issues understanding the meaning of the posts due to their content ambiguity.

In their experimental research study, Goh, Seet and Chen (2012) remarked that administration purposed social media messaging services could contribute to lower-achieving or high risk students in universities. Goh, Seet and Chen noted that social media messaging would improve the self-regulation abilities of these 
student groups. Since the social media has been integrated into these students' lives, schools' persuasive and motivational messages were yielding more instantaneous effect than any other communication channel.

According to Gikas and Grant (2013), quickly accessing school posts, the ability to give feedback, the ability to vote for different polls and the immediate interaction with school staffs have been perceived as the most important elements of social media utilization in a school. However, Gikas and Grant remarked that administrators should not only rely on the easiness of the social media tools by assuming that the tools will be used or accepted by everyone else. Therefore, administrators must promote the tool constantly in which stakeholders will alter their attitudes over time.

In many cases, the mobile messaging feature of social media has been perceived as an instrument for escalated productivity where communication efficiency, decision making timeliness and increased user retention / satisfaction are also maintained. Nevertheless, if these positive outcomes are explained by the recent lower prices of mobile technologies, that would not be enough exploratory. Users' positive experiences, perceived content richness and the extent of providing a social context are significant elements of widespread use of social media messaging tools. Hence, more research studies must be designed to understand these elements deeper in order to foster better cooperation and communication among people or groups (Ogara, Koh \& Prybutok, 2014).

As emphasized above, social media tools could also be used to provide administrative support (such as within-organization communication) in educational organizations. Au-Yong-Oliveira et al. (2018) explicate that today's youth is different in two dimensions; they communicate differently than their older counterparts where communication is mediated mostly by social media, and they prefer to spend less time for reading where visual elements (such as emojis, photos or videos) are becoming more dominant to convey messages to others. Therefore Au-Yong-Oliveira et al. suggested that educational stakeholders must pay special attention to these distinctions in order to optimize processes and procedures in their organizations. For instance other than long emails, shorter social media posts would be much more effective to communicate with their students.

Saorin, de La Torre, Martin and Carbonell (2013) made a point that gaining certain skills and abilities is the ultimate goal of different educational systems all around the world where sometimes instructors do not take advantage of right tools to carry out that skill or ability acquisition processes. In that sense, selection of 
apps among a large set of applications plays an important role. Features such as the interoperability of the mobile apps for different students and their different devices or the ability of group work communication and sharing will play important roles for the apps' acceptability among students. Additionally, one app for all educational aims may not be the best strategy anymore. Hence, the research studies on different apps focusing on their contribution to instructional and managerial processes are essential for a better educational context. In other words, the educational institutions must be aware of different mobile applications with their scopes (instructional versus administrative uses) and services.

In parallel to the variety for social media apps, when the inconceivable usage statistics checked, social media tools suddenly become the center of attention for many organizations all around the world. As Martins, Gonçalves, Oliveira, Cota and Branco (2016) highlighted, impulsive attention does not guarantee the successful implementation of social media in organizations. Martins et al. listed the following points as the achievement criteria; (i) participation of senior/middle level managers, (ii) careful reflection of organizational social media actions onto the organization's business plan, (iii) rivalry pressure on using social media in that organization, and (iv) realization of social media's contributions to that organization. Hence, from the early stages of social media use in higher education, Vrocharidou and Efthymiou (2012) stressed that effective implementation of social media requires its integration into higher education policies. Otherwise, random or not-well-planned actions of social media uses may create an adverse effect on students and instructors, which will hinder other better integration efforts for the future.

Regrettably, the full potential of mobile technologies in higher education has been enlightened or described yet where the educational institutions need more scientific, tool experimented and culture based research studies (Gikas \& Grant, 2013). Therefore, uses of mobile technologies in higher education processes have become a recent research trend which gets attention from different field of studies and focus on different levels (such as learning, assessment or management) (Al-Emran, Elsherif, \& Shaalan, 2016). Dynamic relationship between excellence of higher education and ICT developments (especially mobile technologies) must be analyzed wisely (Watanabe, Naveed \& Neittaanmäki, 2017). In other words, the changes in ICT must be reflected upon higher education practices and the effects must be observed carefully to yield better learning opportunities. Timmis (2012) pointed out that effective administrative uses of online communication tools are ready to offer psychological support to the 
instructional context, starting from motivating students, increasing meaningfulness of many school activities.

When the necessity of research has been unfolded, the next step is to delineate the focusing issues in that framework. Different scholars pay attention to different dynamics of the topic. For example; Panigrahi, Srivastava and Sharma (2018) reported, perception toward the usefulness of a social media tool is the primary driver toward its user adoption. They also noted that this leading factor is not enough to explain any social media tool's well acceptance by public and added several other factors, such as the level of innate self-distraction factors, inherent social media characteristics, level of adjoining support, societal culture of the people, age, and cognitive load as a result of that tool usage.

In the early stages of their study, Al-Emran, Elsherif and Shaalan (2016) assumed that gender, department, level of study are the variables which would make significant differences about using a mobile tool in higher education. On the other hand, in the results, these authors reported that none of these variables made significant differences about attitude of learners $(n=383)$ or instructors $(n=54)$. They also added that only positive attitude was observed in the study participants toward use of mobile technologies in higher education.

Asynchronous versus synchronous communication could be another issue of the topic. Vrocharidou and Efthymiou (2012) pointed out that asynchronous communication tools (such as email) or features (such as posts on social media) of an online platform could bring more satisfaction to educational context where asynchronous tools are perceived as more official communication media and this formal approach is expected from a professional educational institution. Roblyer et al. (2010) also noted that email, as a communication means, is still favorable among instructors.

Mobile apps bringing distraction to personal or educational lives could be another point of study. According to So's research (2016) on social media messenger services, young learners do not feel uncomfortable with messages coming out of the school times such as evening or weekends. Therefore, So (2016) noted that instructional or administrative shares on these services will not hinder learners' personal lives and should be integrated into higher education processes.

Although instructional and communicational uses of social media have been adopted in higher education institutions, universities are still limited in the adoption of social media's administrative aimed utilization. Additionally, Manca and Ranieri (2016) expressed that there is a huge doubt about using social media 
for the management of communication in educational institutions' contexts. In that sense, it is clear that literature needs more studies on taking advantage of different social media apps within the instructional framework, but focusing beyond learning/teaching oriented goals. Therefore, this research focuses on the implementation of a mobile application developed in South Korea for the purposes of providing better communication and administration in educational purposes where the application has been turning a formal tool organized within school policies.

\subsection{Band App in Brief}

As a high-tech country, South Korea has many ICT research and development corporations (World Economic Forum, 2018). Among these advanced technology companies, Naver created Band mobile app which has brought a new approach to social networking. Band is a mobile community application and software assisting to create group communication in a form of social networking service. According to Naver (2017), Band was downloaded more 70 million times around the world. Its popularity was triggered by its adaptation to regular computers and IOS / Android smart phones. Band users can create or become member of groups to foster communication with different purposes, such as family members, study groups, sport teams, fan groups or gaming teams. Band members can review the most popular 'bands', which are groups on Band, and can become members. Band has two major power sources; creating interest-based online communities in the form of groups and utilizing feed feature working on an algorithm stemming from its members' activities and their habitual patterns.

Being the 79th mostly used social networking app, Band is currently available in nine different languages (Apple Store Preview, 2018). According to eMarketer.com (2017), the number of active Band users is far higher compared to the Facebook users in South Korea, even though Facebook is the most popular social media in the world. According to the Band app website, the underlying preference reasons of Band are its accountability with who can access what information, efficiency with organization of Band content, security with its privacy settings and concerns, and participation (Why Band, 2018).

There are five main features offered by Band; Board, Chat, Calendar, Album and Discover. In the Board, members can both share posts and leave comments in the multiple formats such as photos, videos, files, location, poll and event. Additionally, search and hashtag functions make the initiation easy for new users where they can classify the previous content. The second feature, Chat, is 
very similar to what other messenger services offer. Any Band user can start chatting with all of the members or any member s/he chooses. Calendar, as the third Band function, helps Band users save event date, time and ask for RSVP. These group events can be also saved on phone calendar together with an alarm reminder. Album function allows Band users to create photo albums within a group structure. Discover, as the fifth feature, assists Band users to find out other groups that they might think of joining (Band - Organize your groups, 2018). There are other features of Band app, which brings it superiority within the app markets.

When it comes to an instructional focus, Band app reports that it has features for teachers and educational managers (also called as Organizers on the app). Band notes that its group oriented secure communication feature allows teachers, students, administrators and parents to organize educational processes better, such as classroom activity organization (assignments due dates, field trips and etc...) on calendar, or curriculum development activities by chatting, posting information or sharing files with stakeholders, or using Band's polling feature to collect ideas of others for instructional activities or processes, or managing student club activities or team coaching (App for Teachers and Organizers, 2018).

\section{Method}

Learners' ideas and perceptions are indispensably significant for educational institutions whose aim is to use different mobile apps in their organizations. These opinions will guide the decision makers on the development of different technologies' optimal integration strategies (O'Connor \& Andrews, 2018). Therefore, the main objective of this study was to make a general assessment of a South Korean mobile communication app in higher education context where the app was utilized to manage administrative and communication purposes.

The researcher applied a three-step procedure; collecting Band's usage statistics, applying a none-experimental survey with the undergraduate students and conducting an email based open-ended interview with the faculty members. When the researcher decided on the study procedures and finalized the study instruments, the researcher requested permission from the faculty dean to conduct this study. In subsequent to faculty board's formal consent, the researcher first accessed the usage statistics, then announced the online survey on the Band app, and finally reached the faculty members via their emails. The usage statistics were entered on MS-Excel; the survey data was downloaded to an SPSS file and 
analyzed with quantitative techniques. Email responses were collected on an MSWord file and scrutinized with qualitative techniques.

\subsection{The Context and Sample}

As being a case study, it is essential to explain context initially. The focused context was a newly established college of a private university from central South Korean region. The new college was funded by the South Korean government; "University for Creative Korea" University Specialization Project (CK-1) in 2016. Moreover, the college was established in a South Korean city also known as "Silicon Valley of Korea". Because of this innovative structure, all stakeholders within this faculty bring new implementations (such as flipped learning), tools (such as Bluetooth based mobile attendance applications) and procedures (weekly mentor-mentee (faculty member-students) counseling sessions) to the faculty dynamics. The Band app is one of that tools which was used to trigger communication within the college two years ago.

When the faculty members or teaching assistants want to communicate with students, the formal communication tools are either students' emails or messages on LMS. Yet, the students were either not checking their emails on time or not providing the correct email address to university databases. Additionally, LMS messaging is possible only if the students register faculty members' courses, which limit other faculty members' and teaching assistants' communication. Therefore, The faculty members and teaching assistants were complaining about accessing students on time or making class-wise or general announcements.

Moreover, as being a multi-cultural context, different social media tools were popular for different group of students but not all of them (Kakao for Korean students, WeChat for Chinese students and Telegram for Central Asian students). Hence, faculty administration decided to use a small app with relatively easier registration and login processes, called Band.

The Band app was initiated as an informal method of communication among students, teaching assistants (TAs) and faculty members. Hitherto, Band is still keeping its informal structure. However, the content shared on the Band app has gradually turned into more formal topics, such as registrations, announcements on faculty events, course or class re-scheduling, tuition payment issues or internship opportunities.

If someone wants to join a faculty Band group, which works similar to the Facebook closed group logic, s/he must send an invitation to group by answering two basic questions; name and student number. One of the group administrators 
check that answer and approve or reject the membership. Administrators can also send invitations to Band members to join that group, which is a common method when a faculty member wants to join the group.

Unfortunately, from the initiation time, there was no formal or informal assessment of this app implementation. Therefore, the researcher decided to check whether the implementation of Band contributes to the communication and administration dynamics of this context and to make suggestions regarding using such app in higher education institutions.

The Band group that is analyzed in this research paper includes faculty members, teaching assistants as well as students. The group has 200 members including both undergraduate students and faculty members; 1 administrator (the vice dean), 4 co-administrators (three faculty members and the author), 6 faculty members (out of 18 faculty member, excluding the author and other three coadministrators) where 5 faculty members joint the study, and 189 undergraduate students.

Thence, the researcher, as being a member of the administration team and faculty member, has utilized convenience-sampling method, by the fact that some of the participants might be biased (Fraenkel, Wallen \& Hyun, 2012).

\subsection{The Instrument and Data Analysis}

Band group statistics coming from the app itself were collected, tabulated and analyzed in the first part of the study. In the second step of this study, an online survey was conducted among the member students of the faculty Band group. The researcher could not find a survey instrument serving the exact purposes of this study. Therefore, based on Johnson and Christensen (2004) suggestion on developing an instrument from existing literature, the researcher developed the first draft of Band survey. At the end of draft version one, the researcher asked one English language expert to proofread the survey.

Afterwards, the researcher sent the survey to two experts from social media and education fields to collect their feedbacks. As Bolger and Wright (1992) claimed that opinion and feedback gatherings from the experts will increase the content validity. Lastly, the researcher invited two senior students and asked their ideas about the survey. According to Fraenkel, Wallen and Hyun (2012), inclusion of sample representatives into instrument development process will positively influence the content validity. In the light of all these feedback, the researcher finalized the survey and uploaded it to the surveying webpage and shared the link on Band. The researcher did not use other channels of 
communication (such as email or social media) purposefully so that only real Band users will see the survey link.

The survey consists of two parts. The first part, demographics, includes questions about the student's demographics, which helps profile the user's basic information and Band participation level. The second part, the survey questions, focuses on the level of agreement of the student with various statements about the Band app. The second part of the survey was answered on a five scale Likert from 'strongly agree (5)' to 'strongly disagree (1)'. Out of 200 registered Band users, only 52 of them voluntarily filled the survey online. Out of 52 , twenty seven percent $(\mathrm{n}=14)$ is female and seventy three percent $(\mathrm{n}=38)$ is male.

Once the data was collected in one week period, the data was taken to reliability analysis which covered the second part of this survey and revealed a Cronbach alpha of 0.94 with 24 sub-items. Since the result was above 0.60 (Fraenkel, Wallen \& Hyun, 2012), the survey questions were reliable enough to conduct further analysis.

For the last part of the study, the researcher sent an email to all faculty members to collect their ideas, opinions and experiences about the Band group. The collected answers were recorded, themed and analyzed accordingly.

\subsection{The General overview of the Band Group}

Understanding the study context also includes the general usage statistics of Band group. The Band group was created in November 2016, and until the end of November 2018, 1024 posts were made, which were followed by 1941 comments during the two years. As Table 1 shows below, since the opening of the Band group, 275 new members were added, however the recent total number of members was 200 .

Table 1. General Statistics of the Band Group

\begin{tabular}{|c|c|c|c|c|}
\hline & $\begin{array}{c}\text { Total members } \\
\text { added }\end{array}$ & $\begin{array}{c}\text { Total numbers of } \\
\text { visits }\end{array}$ & $\begin{array}{c}\text { Total number of } \\
\text { posts }\end{array}$ & $\begin{array}{c}\text { Total number of } \\
\text { comments }\end{array}$ \\
\hline Total & 275 & 34577 & 1024 & 1941 \\
\hline
\end{tabular}

Although 75 members left Band group, it seemed that Band Group was gradually increasing its popularity among the stakeholders. From Table 2, it can be clearly seen that the Band group slowly became popular as the number of posts being made each month increased gradually over the two years. The number of posts was lower during the winter and summer vacations that was mostly two posts a day compared to more than 10 posts during final exams. The data shows 
that majority of the group posts were submitted by faculty members and teaching assistants.

Table 2. Total number of posts per month

\begin{tabular}{|c|c|c|c|c|c|c|c|c|c|c|c|c|}
\hline & Jan & Feb & Mar & Apr & May & Jun & Jul & Aug & Sep & Oct & Nov & Dec \\
\hline $\mathbf{2 0 1 6}$ & - & - & - & - & - & - & - & - & - & - & 1 & 0 \\
\hline $\mathbf{2 0 1 7}$ & 0 & 1 & 37 & 56 & 23 & 19 & 8 & 4 & 29 & 43 & 73 & 50 \\
\hline $\mathbf{2 0 1 8}$ & 21 & 8 & 133 & 49 & 43 & 52 & 36 & 61 & 73 & 105 & 99 & - \\
\hline
\end{tabular}

The total number of Band Group visits for each month was another estimator showing the popularity of the group among the students. The Table 3 below clearly shows the differences in the number of visits in different months. The same pattern with the number of posts can be seen here that more students visited the Band Group during the semester than summer and winter vacations.

Table 3. Total number of visits per month

\begin{tabular}{|c|c|c|c|c|c|c|c|}
\hline Months & $\mathbf{2 0 1 6}$ & $\mathbf{2 0 1 7}$ & $\mathbf{2 0 1 8}$ & Months & $\mathbf{2 0 1 6}$ & $\mathbf{2 0 1 7}$ & $\mathbf{2 0 1 8}$ \\
\hline Jan & - & 7 & 1040 & Jul & - & 476 & 1808 \\
\hline Feb & - & 114 & 470 & Aug & - & 204 & 2161 \\
\hline Mar & - & 1206 & 3170 & Sep & - & 979 & 2619 \\
\hline Apr & - & 1438 & 2059 & Oct & - & 1193 & 3401 \\
\hline May & - & 1074 & 1872 & Nov & 25 & 1532 & 3166 \\
\hline Jun & - & 851 & 2122 & Dec & 13 & 1577 & - \\
\hline
\end{tabular}

Finally yet importantly, the app data unfolds that the busiest days of the group were Thursday and Friday, with highest number of visitors and posts respectively (Figure 1). This data essentially shows that if the administration or faculty members want to transfer a message to the students, these days would increase the likelihood of transferring the message to highest amount of students.

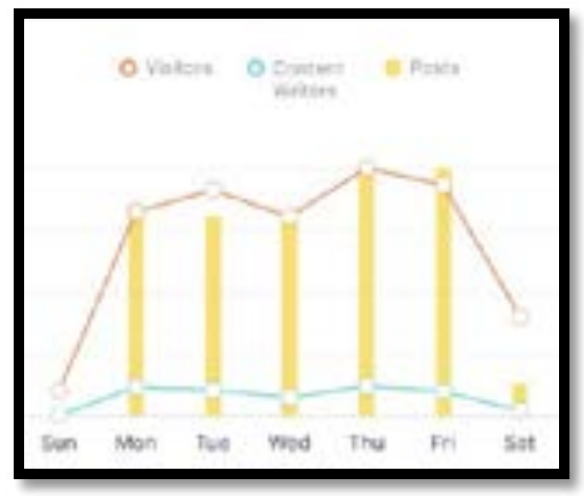

Figure 1. Daily visits 


\section{Results}

\subsection{The Survey with Students}

The key variables in this study were measured by the answers to the online survey. The first part of the instrument included 19 demographic questions such gender, the level of study and the country of origin and respondent's frequency of profile checking, completeness of his or her profile (full name, photo) and awareness of the policies of Band. The second part consisted of 24 statements, to which students need to show their level of agreement by choosing one of the options on 5-level Likert scale from "Strongly Agree" to "Strongly Disagree". The last open-ended question was about the possible improvements on Band Group, which is very important to the school administration as well as to the researcher to understand the possible ways of developing the group. Overall, 52 students took the online survey out of 189 student group members $(28 \%$ completion rate).

As Table 4 shows, most of the respondents were freshman year and male students. Since South Korean higher education system is different from many other countries (4 semesters per year), some participants noted that they were junior students in a two-year school. Furthermore, since the faculty was international, respondents' country of origin were also listed as; Uzbekistan $(n=34)$, South Korea $(n=6)$, Bangladesh $(n=6)$, Nepal $(n=5)$, and Pakistan $(n=1)$.

Table 4. Gender versus level of schooling for study participants

\begin{tabular}{|c|c|c|c|c|}
\hline \multicolumn{2}{|c|}{} & \multicolumn{2}{|c|}{ Gender } & \\
\cline { 3 - 5 } \multicolumn{2}{|c|}{} & Female & Male & Total \\
\hline \multirow{3}{*}{$\begin{array}{c}\text { Level of } \\
\text { Schooling }\end{array}$} & Freshman & 8 & 22 & 30 \\
\cline { 2 - 5 } & Sophomore & 6 & 11 & 17 \\
\cline { 2 - 5 } & Junior & 0 & 5 & 5 \\
\cline { 2 - 5 } & Total & 14 & 38 & 52 \\
\hline
\end{tabular}

The fourth question was about how long the students had been using Band in months. As Figure 2 shows, the months vary from 1 to 24, with an average of 11 months with a standard deviation of 6 months. Most of the students had more than a year of experience on using Band app. 


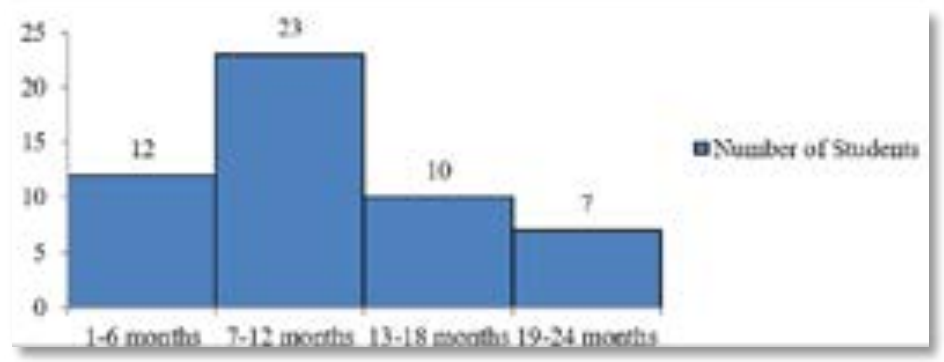

Figure 2. The histogram of students' Band membership duration

The next part of the questions asks how active the students were on Band and their awareness of rules of the app. When the students were asked how often they check their profiles, the answers were grouped: around 5 times in a day; less than 5 times a day $(\mathrm{n}=19,36.5 \%)$ and more than 5 times a day $(\mathrm{n}=15,28.8 \%)$. The other options are as follows in the order of frequency; once in a day $(\mathrm{n}=7$, $13.5 \%)$, twice a day $(\mathrm{n}=5,9.6 \%)$, once in a week $(\mathrm{n}=4,7.7 \%)$, and once in two days $(\mathrm{n}=2,3.8 \%)$. As the data says, the students check their Band Group very often.

Additionally, the students added that they mostly use their full name on their Band profiles $(\mathrm{n}=49,94.2 \%)$. Only four students answered as "no" by stating security purposes $(n=3)$ and limited name field size $(n=1)$. All but one student checked that they had their own profile photo on Band. The students were also asked whether they were members of any other Band group other than faculty Band group. $77 \%$ of them answered negatively $(n=40)$, yet $23 \%$ was positive $(\mathrm{n}=12)$.

The students were asked if they used chat feature of Band Group with their classmates or with their faculty members. For both situations, the use of chat was not common (43 and 37 students respectively). On the other hand, 15 students $(29 \%)$ reported that they chatted with their faculty members whereas only nine students (17\%) said they chatted with their classmates on Band Group. When reasons of not-using chat with their classmates were asked, the students listed using other chat programs $(n=11)$, not common to chat $(n=1)$, no reason to chat $(\mathrm{n}=1)$, and preference on face-to-face communication $(\mathrm{n}=1)$. Additionally, the same question for the faculty member chat point of view was asked, the answers were; preference on sending an email $(n=4)$ and on having a face-to-face meeting $(n=4)$. 
Next two questions were about posting on Band Group. 40 students (77\%) noted that they commented on Band Group posts. On the other hand, only 14 students (27\%) pointed that they posted something on Band Group. The rest of the students $(\mathrm{n}=10)$ claimed that they prefer to follow the posts other than submitting posts.

The students were asked whether they check and join to the popular groups on Band, 41 students (79\%) answered adversely. The students were asked if they checked trending posts on Band, the answers were nearly half-and-half; 25 yes and 27 no.

Since the medium of instruction in the faculty was English, which was no one's mother tongue, the question was important to check if they felt and language barrier when they used Band Group. 29 students (56\%) were reported negatively, yet 23 students (44\%) noted that they experienced language related problems on Band Group.

A specific focus on privacy and confidentiality issue was unfolded with four questions. In the initial question, 27 students (52\%) reported that they were not aware of Band's efforts to protect youth. Later a question on reading Band's privacy policy was answered as No $(n=32,62 \%)$ more than Yes $(n=20,38 \%)$, where two students noted as no-interest, one as no-care and one as not-important. Moreover, 27 students (52\%) reported that they never read Band's Terms of Use where four students wrote that they had no-interest in reading the terms. Similarly, 25 students (48\%) pointed that they were not aware of Band's Operation Policy.

After 19 demographic and informative questions, the students were given 24 statements on the Band app and asked to answer on a 5-Likert scale (from strongly disagree to strongly agree). Table 5 shows the items, their mean scores and standard deviations (re-ordered from the highest to the lowest mean scores).

Table 5. The survey items and their basic statistics

\begin{tabular}{|ll|c|c|}
\hline \multicolumn{1}{|c|}{ Survey Item } & M & S.D. \\
\hline 1. I think installing Band is easy. & 4.13 & 0.60 \\
\hline 2. I find professors' posts useful. & 4.08 & 0.95 \\
\hline 3. I like to read professors' posts on Band. & 4.06 & 0.80 \\
\hline $4 . \quad$ I find Band useful. & 4.04 & 0.79 \\
\hline 5. I think registration to Band is easy. & 4.00 & 0.74 \\
\hline 6. Information on Band interface is easy to read. & 3.96 & 0.82 \\
\hline 7. I find teaching assistants' posts useful. & 3.94 & 1.19 \\
\hline 8. I like that my school has Band app. & 3.92 & 0.99 \\
\hline 9. I like to read teaching assistants' posts on Band. & 3.88 & 1.13 \\
\hline 10. It is easy to use Band. & 3.87 & 0.84 \\
\hline
\end{tabular}




\begin{tabular}{|l|c|c|}
\hline \multicolumn{1}{|c|}{ Survey Item } & M & S.D. \\
\hline 11. Band can contribute to education. & 3.69 & 0.94 \\
\hline 12. I can easily approach to my professors on Band. & 3.67 & 0.88 \\
\hline 13. I like that we can share files on Band app. & 3.67 & 0.96 \\
\hline 14. I like to read other students' posts on Band. & 3.56 & 1.06 \\
\hline 15. I can offer other schools to use Band app. & 3.56 & 1.04 \\
\hline 16. I believe that Band is a secure application. & 3.54 & 0.78 \\
\hline 17. Band has become a part of my daily routine. & 3.50 & 1.24 \\
\hline 18. I can offer companies should also use Band app. & 3.44 & 1.00 \\
\hline 19. I think our Band group is managed well. & 3.42 & 1.26 \\
\hline 20. I find other students' posts useful. & 3.40 & 1.14 \\
\hline 21. I feel no discrimination on Band. & 3.25 & 1.19 \\
\hline 22. I intend to use Band in the future. & 3.25 & 1.01 \\
\hline 23. Band is not for an educational institution. & 1.87 & 0.93 \\
\hline 24. I keep in touch with my classmates on Band. & 2.79 & 1.18 \\
\hline
\end{tabular}

Although none of the scores exceeds 4.50 , students were happy that faculty was using the Band app. Moreover, the participants agreed that Band is for educational institutions. On the other hand, the mean score for offering the same app to other schools was lower than the overall happiness score. The same score was even lower for offering the Band app to companies. It seems that students were more moderately hesitant to suggest Band app to other schools.

When the mean scores are considered, it seems that students perceive the Band app as easy-to-install, easy-to-register and easy-to-use. That is why; the students moderately agreed that Band app has become one of their daily routines. Besides, students gave higher scores to professors' posts' usefulness and liking than the teaching assistants. On the other hand, students did not agree that other students' posts were useful for themselves, which could stem from the reason of not-trusting the content.

Nevertheless, the students notified that existing Band group was managed well by the administrators. The students more or less believed that there was discrimination on Band group. Lastly but not least, students did not prefer to keep in touch with their classmates or their professors on Band for one-to-one communication.

The survey ends with the question of "Is there anything else do you want to add about Band and its utilization in our college?" Nine students answered the open-ended question. The following points were summarized from their comments: Other than everything, only important and useful posts should be posted which will disturb students less $(\mathrm{n}=1)$, Other than only faculty related posts, posts from general university events or activities must be shared as well, Band posts must be error free (not only the content but also grammar and spelling) 
so that students will not misunderstand the content, Band posts must be doublechecked to prevent from demeaning students attitude, and Preference on use of emails with Band posts.

\subsection{Comparison Tests}

In order to understand the Band related perception more deeply, the researcher applied comparison tests to the data set. Since the data failed from normal distribution tests, the researcher followed the non-parametric approach to the data set. First, the researcher checked whether the level of study (from freshman to senior) makes a difference on survey items. According to KruskalWallis tests, none of the items made a difference on that variable $(\mathrm{p}=0.05)$.

Mann-Whitney $U$ test was utilized for checking whether gender (male versus female) made a significant difference on survey items. Items 15 (I like to read other students' posts on Band) and 21 (I feel no discrimination on Band) showed significant differences according to gender variable $(\mathrm{n}=14$ for female and $\mathrm{n}=38$ for male). For item 15 , the result of the test was statistically significant, $\mathrm{z}=-$ $2.06, \mathrm{p}<.05$ where $\mathrm{U}$ is equal to 172.00 . Female students had an average mean rank of 33.21, while make students had an average mean rank of 24.03. Therefore, it seemed that female students like to read other students' Band posts more than male students. For item 21 , the result of the test was statistically significant, $z=-$ $2.57, \mathrm{p}<.05$ where $\mathrm{U}$ is equal to 146.50 . Female students had an average mean rank of 35.04, while make students had an average mean rank of 23.36. Therefore, it seems that female students feel more discrimination on Band than male students.

\subsection{The Ideas of Faculty Members and Teaching Assistants}

After the student data collection phase, the researcher sent an email to all other faculty members ( $\mathrm{n}=18$, excluding the author) asked their thoughts on the use of Band in faculty. Since only seven faculty members (39\%) were registered to Band, the response rate was only five faculty members out of six (excluding the author). When these seven faculty members' responsibilities checked, it was found that they are mostly assigned to administrative tasks, such as vice dean $(\mathrm{n}=1)$, career development coordinators $(\mathrm{n}=2)$ and managers of international student counseling $(n=2)$. All the faculty members agreed that Band app was very useful for inner-faculty communication and an easy to learn tool.

When their responses analyzed qualitatively thoroughly, the following points were reported; 
- Professors like receiving updates about faculty activities on Band app.

- Band app is bringing more communicational advantages in the form of announcements, since students do not check their email regularly or do not visit LMS daily.

- Other faculty members and students must also be introduced and encouraged to join Band app. Especially, students should be introduced with Band app during their orientation week.

- More real life news and stories should be posted to Band app.

- Faculty related success outcomes (such as new cooperation agreements with other organizations) should be shared with students on Band app.

- Posts should have at least one photo to get students' attention. As the vice dean stated "Posts without photos don't get often noticed".

- Announcements / posts should be categorized with certain common titles.

- Sub-groups within faculty Band app group should be set to have an open discussion platform to know more about students' opinions and views on certain technical / educational topics.

- "Scheduling appointment tool" of Band app should be used more often, especially when the students want to take an appointment from faculty members.

- Students are sometimes commenting or posting their views and opinions inappropriately. Thus, Band app rules must be established to avoid any student misbehaviors.

- One of the faculty members shared his concerns that official announcements (such as registration or evaluation issues) should also be done via student emails too. Otherwise, the students might deny that they are informed about certain procedures effectively. Alternatively, Band app must be recognized as an official tool by the university. The same faculty member also added that only one channel of official communication must exist, otherwise several means of communication might create conflicts in the future.

Lastly, the author asked the opinions of teaching assistants who were the administrators of faculty Band app group. They generally noted two major complaints; the frequency of direct messages on the Band app to teaching assistants who purposefully neglect them and the difficulty of keeping important announcements at the top of the Band feed.

\section{Discussions and Conclusion}

Similar to many other scholars' (Gikas \& Grant, 2013; Manca \& Ranieri, 2016) comments on unstoppable attractiveness of social media, the Band app of 
this study has gained more attention in two years with an increase in its number of members, daily visits, posts, comments, chats and other Band groups joint. It is also noteworthy that this increase in use has occurred without any formal obligation within the faculty structure. Therefore, we can see a reciprocal fondness between the app usage ratings and feeling necessity toward having a tool to utilize within faculty communication or administration support. In other words, the students, professors and administrators have created a consensus on the contributions of the Band app, thus they have tended to utilize it more. In that sense, it could be concluded that by stemming from social media's popularity and uses, it would not be difficult to integrate a new social media tool (like Band in this study) for a faculty / department for better communication and fostering administration procedures.

Announcing such an app as a formal way of communication or administration creates a dilemma. On one side, educational institutions should internalize the tool as one of their formal way of interaction. As Gikas and Grant (2013) noted, the formalization would help the managers to realize whether there exists an attitude change toward using that tool effectively. Moreover, as some students wrote in the open-ended comments part of this study survey, formalization will initiate taking the posts more seriously among the students. In other words, when there is a notification from the app, the students would avoid from neglecting that notification based on its probability of significance.

On the other hand, the emphasis on the app as a formal tool might build a wall between students and non-students elements of the educational context. Hence, the flow of the information or communication would mostly (or even only) be one way from non-students (professors or other administrators) to students which would make students as the passive receiver of the interaction. Additionally, by considering the cultural differences and their effects on communication (Panigrahi, Srivastava \& Sharma, 2018), this very formal management of mobile apps might bring adverse outcomes to the context. Especially, South Korea, which is the context for this study, which has been known as a traditionalist country (Confucianism still dominates the society) with certain predefined borders between students and professors. As Hofstede Insights (2021) also emphasized, South Korea is a moderately hierarchical society where the power distance between a student and a faculty member is highly expected and justified. As the international students spend more time in South Korea, they also internalize the traditionalist attitude up to a certain level. In that case, international students imitate their Korean classmates for their school interactions. Thus, Band has been essential to eradicate some of these existing borders. 
The close examination on monthly visits, monthly posts and daily visits is essential to understand the dynamics of communication among the stakeholders. For example; once the students' most active month(s) and day(s) revealed, the administration or course instructors could deliver their messages accordingly. That will increase the likelihood of message transfer to the related bodies on time. Moreover, a content analysis of the posts would be helpful to unfold the general issues regarding management and administration.

In a nutshell, the optimal solution could be integrating such mobile apps into administrative strategies officially (Martins, et al., 2016; Vrocharidou \& Efthymiou, 2012) to demonstrate students that these apps and posts are important for them, while giving students freedom to express themselves as they wish without putting any pressure. Of course, rules must be established in that strategic plan, especially covering the language related issues such as personal attacks or offences (Naismith, 2007).

When the general results of the study are considered, Band users have no technical issues with its installation or utilization. Error-free apps offer better experiences to their users. Thus, higher education institutions must check the best fitted mobile app for their bodies, and conduct a pilot study, if possible. Despite the fact that students like moderation by research assistants, they prioritized the significance of the posts. That might negatively affect the accessibility of some posts led by other students (such as student club activities). Hence, administration must develop a policy showing that all the posts are equally important once it is announced on that mobile app. Yet, as some professors and students highlighted, emailing should not be neglected from the communication processes. Otherwise, posting several shares might end up with missing some important announcements on the app.

The Chat feature of Band was another controversial element of the study. While the students were pointing that they preferred to have face-to-face communication with their managers, classmates or professors, we still know that they are using other messaging applications for their friends. The researcher believes that students do not know about the existence of group messaging (aka chatting) feature or the possibility of creating a special group messaging room on Band where the entire class could share their concerns, comments or ideas on that group chat, very similar to all other messaging apps. As Goh, Seet and Chen (2012) noted, chatting offers many positive effects for different group of students; such as low-achievers or introverted. Therefore, a further study could be established to 
compare students' communication on their personal social media tools and Bandwise formal application.

Beyond the issues discussed above, Band app has been accepted as a valuable tool in the context of the study. Therefore, it could be concluded that certain mobile apps like Band have readily been offering advantages in communication and administration dimensions for the educational institutions. Although there are not many mobile app implementations in these dimensions, cases studies (Goh, Seet, \& Chen, 2012; Jones, Edwards, \& Reid, 2009; Naismith, 2007; So, 2016) like this study still offer experimentation and integration opportunities for stakeholders.

This paper shows a brighter picture that the schools can add more value to their educational processes by implementing a simple social media tool, as the technology now covers most of people's lives and that education should not be behind that. The results of this research should be helpful for the schools that are planning to adapt different social media apps into their organizations.

While this study points out certain issues regarding to adaptation of a social media tool for administrative and communicative purposes for different educational institutions, the results might also offer certain solutions to social media app developers. For example, the features like better categorization or prioritization of the posts, post - email synchronization, special feature offering for instructors, etc...

When focused on the limitations of the study, it is clear that number of participants was not enough to make deeper analyses on Band's implementation. Therefore, the app must be implemented in another case with a larger sample where the researcher(s) will have a bigger data to make further analyses. Additionally, an important step of interviewing should be added to research design to comprehend the effects or perceptions regarding Band or similar administration / communication tools in educational institutions. Moreover, the same app could be analyzed by interviewing the professors and administration bodies.

In another dimension, the researcher recommends conducting similar research based on Band-wise apps in different universities and countries. When universities are focused, the researcher highly suggests making a comparative study among different faculties and departments as different field of studies have different means or ways of communication and management (especially technology dominant departments versus less technology leading departments). 
The same comparisons should be handled among countries of different technological development levels; such as high-tech versus technologically developed versus developing.

\section{References}

AL-EMRAN, M., Elsherif, H. M., \& Shaalan, K. (2016), "Investigating attitudes towards the use of mobile learning in higher education", Computers in Human Behavior, 56, pp. 93-102. https://doi.org/10.1016/j.chb.2015.11.033

APP FOR TEACHERS AND ORGANIZERS (2018), App for teachers and organizers, https://band.us/about/school-app

APPLE STORE PREVIEW. (2018), Band - App for all groups, https://itunes.apple.com/app/id542613198?mt=8

AU-YONG-OLIVEIRA, M., Gonçalves, R., Martins, J., \& Branco, F. (2018), "The social impact of technology on millennials and consequences for higher education and leadership", Telematics and Informatics, 35(4), pp. 954-963. https://doi.org/10.1016/j.tele.2017.10.007

BAND - Organize your groups. (2018), Band - Organize your groups, https://band.us/

BOLGER F., \& Wright G. (1992), "Reliability and validity in expert judgment", Expertise and Decision Support, Springer, Boston, MA, pp. 47-76.

eMARKETER (2017, January 09), South Korean social apps hold off Facebook - for now, https://www.emarketer.com/Article/South-Korean-SocialApps-Hold-Off-Facebookfor-Now/1014993

FRAENKEL, J. R., Wallen, N. E., \& Hyun, H. H. (2012), How to design and evaluate research in education (8th ed.), New York: McGraw-Hill.

GIKAS, J., \& Grant, M. M. (2013), "Mobile computing devices in higher education: Student perspectives on learning with cellphones, smartphones \& social media", Internet and Higher Education, 19, pp. 18-26. https://doi.org/10.1016/j.iheduc.2013.06.002

GOH, T., Seet, B., \& Chen, N. (2012), "The impact of persuasive SMS on students' self-regulated learning", British Journal of Educational Technology, 43(4), pp. 624-640. https://doi.org/10.1111/j.14678535.2011.01236.x 
HOFSTEDE INSIGHTS (2021), Country comparison, https://www.hofstedeinsights.com/country-comparison/south-korea/

JOHNSON, R. B., \& Christensen, L. B. (2004), Educational Research: Quantitative, Qualitative, and Mixed Approaches, Boston, MA: Allyn and Bacon.

JONES, G., Edwards, G., \& Reid, A. (2009), "How can mobile SMS communication support and enhance a first year undergraduate learning environment?", ALT-J. Research in Learning Technology, 17(3), pp. 201-218. https://doi.org/10.1080/09687760903247625

MANCA, S., \& Ranieri, M. (2016), "Facebook and the others. Potentials and obstacles of social media for teaching in higher education", Computers \& Education, $\quad 95, \quad$ pp. 216-230, https://doi.org/10.1016/j.compedu.2016.01.012

MARTINS, J., Gonçalves, R., Oliveira, T., Cota, M., \& Branco, F. (2016), "Understanding the determinants of social network sites adoption at firm level: A mixed methodology approach", Electronic Commerce Research and Applications, 18, pp. 10-26. https://doi.org/10.1016/j.elerap.2016.05.002

NAISMITH, L. (2007), "Using text messaging to support administrative communication in higher education", Active Learning in Higher Education, $8(2), \quad$ pp. 155-171. https://doi.org/10.1177/1469787407078000

NAVER (2017), Company. https://www.navercorp.com/en/naver/company

O'CONNOR, S., \& Andrews, T. (2018), "Smartphones and mobile applications (apps) in clinical nursing education: A student perspective", Nurse Education Today, 69, pp. 172-178, https://doi.org/10.1016/j.nedt.2018.07.013

OGARA, S. O., Koh, C. E., \& Prybutok, V. R. (2014), "Investigating factors affecting social presence and user satisfaction with mobile instant messaging", Computers in Human Behavior, 36, pp. 453-459. https://doi.org/10.1016/j.chb.2014.03.064

PANIGRAHI, R., Srivastava, P. R., \& Sharma, D. (2018), "Online learning: Adoption, continuance, and learning outcome - A review of literature", International Journal of Information Management, 43, pp. 1-14. https://doi.org/10.1016/j.ijinfomgt.2018.05.005 
ROBLYER, M. D., McDaniel, M., Webb, M., Herman, J., \& Witty, J. V. (2010), "Findings on Facebook in higher education: A comparison of college faculty and student uses and perceptions of social networking sites", Internet and Higher Education, 13(3), pp. 134-140. https://doi.org/10.1016/j.iheduc.2010.03.002

SAORIN, J. L., de La Torre, J., Martin, N., \& Carbonell, C. (2013), "Education working group management using digital tablets", Presented at 3rd World Conference on Learning, Teaching and Educational Leadership (WCLTA-2012). Procedia: Social and Behavioral Sciences, 93, pp. 1569-1573. https://doi.org/10.1016/j.sbspro.2013.10.083

SO, S. (2016), "Mobile instant messaging support for teaching and learning in higher education", Internet and Higher Education, 31, pp. 32-42. https://doi.org/10.1016/j.iheduc.2016.06.001

TIMMIS, S. (2012), "Constant companions: Instant messaging conversations as sustainable supportive study structures amongst undergraduate peers", Computers \& Education, 59(1), pp. 3-18. https://doi.org/10.1016/j.compedu.2011.09.026

VROCHARIDOU, A., \& Efthymiou, I. (2012), "Computer mediated communication for social and academic purposes: Profiles of use and university students' gratifications", Computers \& Education, 58(1), pp. 609-616. https://doi.org/10.1016/j.compedu.2011.09.015

WATANABE, C., Naveed, K., \& Neittaanmäki, P. (2017), "Co-evolution between trust in teachers and higher education toward digitally-rich learning environments", Technology in Society, 48, pp. 70-96. https://doi.org/10.1016/j.techsoc.2016.11.001

WHY BAND (2018), Why Band. https://band.us/about/why-band

WORLD ECONOMIC FORUM (2018, February 06), South Korea and Sweden are the most innovative countries in the world, https://www.weforum.org/agenda/2018/02/south-korea-and-swedenare-the-most-innovative-countries-in-the-world/ 